\title{
PEMBANGUNAN WEBSITE INFORMASI SEKOLAH DI SMA NEGERI KERJO, KARANGANYAR
}

\author{
Yogiek Indra Kurniawan ${ }^{1}$ \\ ${ }^{1}$ Universitas Muhammadiyah Surakarta. Email: yogiek@ums.ac.id
}

\begin{abstract}
SMA Negeri Kerjo is a senior high school located in Kerjo, Karanganyar regency, Central Java province. From the data obtained, it can be seen that SMA Negeri Kerjo included in the school that is developing. There are more people willing to enter this school, especially high school student candidate in Kerjo area, Karanganyar regency. Based on the interviews that have been done, there are some problems in SMA Negeri Kerjo. The main problem is the promotion of SMA Negeri Kerjo that has not been maximized. During this time, the promotion from SMA Negeri Kerjo to capture the students is through posters spread to the surrounding areas. Another problem is the number of information related to SMA Negeri Kerjo that want to be conveyed to the public, both to SMA Negeri Kerjo's students, as well as to people who want to know the condition in SMA Negeri Kerjo. Based on the problems above, the solution to overcome these problems is with the school information website that specifically displays the information for SMA Negeri Kerjo. SMA Negeri Kerjo's website has been built with several features, including : school module, news module, gallery module, guest book module, PPDB module, material download module, announcement module, and extracurricular activity module. Based on the tests that have been done, 96.67\% of respondents stated that the SMA Negeri Kerjo's website can provide information on matters related to schools, news and school activities well, 85.83\% of respondents stated that the website can already be a promotional tool which is better than the existing posters and fliers as well as $98.33 \%$ of respondents stated that the website is feasible to use.
\end{abstract}

Keywords: school, senior high school, website

\begin{abstract}
ABSTRAK
SMA Negeri Kerjo adalah sebuah sekolah tingkat menengah atas yang terletak di daerah Kerjo, kabupaten Karanganyar, provinsi Jawa Tengah. Dari data yang diperoleh, dapat diketahui bahwa SMA Negeri Kerjo termasuk ke dalam sekolah yang sedang berkembang. Semakin banyak yang berkeinginan untuk memasuki sekolah ini, terutama para calon siswa SMA di daerah Kerjo, kabupaten Karanganyar. Berdasarkan wawancara yang telah dilakukan, terdapat beberapa permasalahan di SMA Negeri Kerjo. Permasalahan yang utama adalah promosi SMA Negeri Kerjo yang belum maksimal. Selama ini, promosi yang dilakukan SMA Negeri Kerjo untuk menjaring siswa hanyalah melalui poster yang disebar ke daerah-daerah sekitar. Permasalahan yang lain adalah banyaknya informasi terkait SMA Negeri Kerjo yang ingin disampaikan kepada publik, baik kepada siswa SMA Negeri Kerjo, maupun kepada masyarakat yang ingin mengetahui kondisi di SMA Negeri Kerjo. Berdasarkan permasalahan di atas, solusi yang dilakukan untuk mengatasi berbagai permasalahan tersebut adalah dengan adanya website informasi sekolah yang khusus menampilkan informasi-informasi untuk SMA Negeri Kerjo. Website SMA Negeri Kerjo pun telah dibangun dengan beberapa fitur, antara lain : modul sekolah, modul berita, modul gallery, modul buku tamu, modul PPDB, modul download materi, modul pengumuman, serta modul kegiatan ekstrakurikuler. Berdasarkan pengujian yang telah dilakukan, 96,67\% responden menyatakan bahwa website SMA Negeri Kerjo dapat memberikan informasi mengenai hal-hal yang berkaitan dengan sekolah, berita serta kegiatan sekolah dengan baik, 85,83\% responden menyatakan bahwa website tersebut sudah dapat menjadi alat promosi yang lebih baik daripada poster dan flier yang ada selama ini serta 98,33\% responden menyatakan bahwa website tersebut sudah layak untuk digunakan.
\end{abstract}

Kata Kunci: Sekolah, SMA, Website 


\section{PENDAHULUAN}

SMA Negeri Kerjo adalah sebuah sekolah tingkat menengah atas yang terletak di daerah Kerjo, kabupaten Karanganyar provinsi Jawa Tengah. Sekolah ini berlokasi di Jalan Sumberejo, RT01/02, Dusun Kerjo, Kelurahan Sumberejo, Kabupaten Karanganyar, Provinsi Jawa Tengah. SMA ini mulai menjalankan kegiatan operasional pada tanggal 5 Mei 1991. SMA Negeri Kerjo merupakan sekolah yang memiliki jumlah siswa dalam kategori cukup banyak. Data yang diambil pada tanggal 12 November 2017 menunjukkan jumlah siswa untuk SMA Negeri Kerjo sebanyak 793 siswa yang terbagi menjadi : 282 siswa untuk kelas X, 239 siswa untuk kelas XI dan 272 siswa untuk kelas XII. Dalam beberapa tahun terakhir, jumlah siswa di SMA Negeri Kerjo selalu mengalami peningkatan. Untuk mengurus sekolah tersebut, terdapat total 58 pegawai yang terdiri dari 43 guru dan 15 tenaga pendidik di tahun 2017. Jumlah guru dan tenaga pendidik pun bertambah dari tahun ke tahun. Hal ini sejalan pula dengan peningkatan sarana prasarana dengan jumlah ruang kelas di tahun 2017 ini mencapai 24 ruang, beserta 3 lab dan 1 perpustakaan. Dari data yang didapat di atas, dapat diketahui bahwa SMA Negeri Kerjo termasuk ke dalam sekolah yang sedang berkembang. Semakin banyak yang berkeinginan untuk memasuki sekolah ini, terutama para calon siswa SMA di daerah Kerjo, kabupaten Karanganyar.

Berdasarkan wawancara yang dilakukan kepada kepala sekolah SMA Negeri Kerjo, bapak Drs. Sunarso, M.Pd, pada tanggal 12 November 2017, terdapat beberapa permasalahan di SMA Negeri Kerjo. Permasalahan yang utama adalah promosi SMA Negeri Kerjo yang belum maksimal. Selama ini, promosi yang dilakukan SMA Negeri Kerjo untuk menjaring siswa hanyalah melalui poster yang disebar ke daerah-daerah sekitar. Karena hanya berbentuk poster, maka informasi yang diberikan juga sangatlah minim, sehingga banyak calon peserta didik yang harus melakukan telepon atau datang langsung ke SMA Kerjo untuk bertanya mengenai SMA tersebut, baik tata cara pendaftaran masuk, maupun biaya dan lain sebagainya. Permasalahan yang lain adalah banyaknya informasi terkait SMA Negeri Kerjo yang ingin disampaikan kepada publik, baik kepada siswa SMA Negeri Kerjo, maupun kepada masyarakat yang ingin mengetahui kondisi di SMA Neger Kerjo. Contoh informasi yang ingin dipublikasikan antara lain kegiatankegiatan yang dilangsungkan di sekolah, materi pembelajaran untuk siswa, berita terkini yang terjadi di sekolah, info PPDB (Penerimaan Peserta Didik Baru), karya tulis ilmiah serta kegiatan ekstrakurikuler di sekolah, maupun informasi yang lainnya. Hanya saja, selama ini untuk menyebarkan informasi, pihak sekolah hanya menempelkan informasi tersebut di mading (majalah dinding) sekolah yang dirasa sangat tidak efektif. Sehingga diperlukan media / sarana untuk penyebaran informasi kepada publik secara lebih luas dan efisien.

\section{METODE PELAKSANAAN}

Menurut Rahman (2018), Aplikasi berbasis website dapat memudahkan berbagai macam proses manual. Sedangkan menurut Marlena, N., \& Sasongko, D. (2012), website informasi sekolah merupakan solusi atas permasalahan penyebaran informasi di sekolah. Dengan adanya website yang dapat diakses secara online, setiap kalangan dapat melihat semua informasi yang dibutuhkan menggunakan device yang dimiliki asalkan terkoneksi jaringan internet.

Sependapat dengan Marlena, telah dibangun sebuah website informasi sekolah oleh (Suhartanto, 2017) di SMP Negeri 3 Delangu. Website ini dapat mengakomodasi penyebaran informasi di SMP tersebut dan menjadi media efektif untuk pertukaran informasi antara pihak sekolah maupun pihak luar sekolah. Dengan adanya website ini, 
maka pihak di luar sekolah dapat mengetahui info maupun berita dari sekolah tersebut. Hal ini memudahkan pihak luar sekolah untuk selalu terhubung dengan pihak sekolah. Website menjadi sarana yang efektif dalam menyelesaikan permasalahan lack of information yang ada.

Supriyono et all (2016) juga telah menerapkan teknologi website di SMP Muhammadiyah 1 Kartasura dan SMA Muhammadiyah 4 Kartasura. Website tersebut dapat menampilkan semua informasi dari sekolah serta memberikan dampak yang signifikan terhadap promosi sekolah. Tahapan pembuatan website dimulai dari observasi di 2 sekolaht tersebut, kemudian pembuatan website sekolah sampai maintenance / perawatan sehingga website tersebut dapat berjalan dengan baik dan digunakan oleh pihak sekolah.

Berdasarkan permasalahan pada mitra di atas, solusi yang ditawarkan untuk mengatasi berbagai permasalahan tersebut adalah dengan adanya website informasi sekolah yang khusus menampilkan informasi-informasi untuk SMA Negeri Kerjo. Selama ini, SMA Negeri Kerjo belum memiliki website yang menampilkan informasi di sekolahnya. Dengan adanya website informasi tersebut, pihak sekolah dapat memberikan informasi secara luas kepada publik mengenai tata cara pendaftaran, info PPDB maupun keadaan sekolah. Selain itu, pihak sekolah juga dapat memberikan informasi kepada siswa-siswa sekolahnya mengenai kegiatan-kegiatan di sekolah secara lebih efektif dan efisien, karena siswa hanya perlu membuka website sekolah dengan koneksi internet yang telah disediakan oleh sekolah menggunakan handphone, tablet maupun laptop pribadi masing-masing. Dengan adanya website, maka pihak sekolah dapat terhubung secara lebih mudah dengan pihak di luar sekolah. Ketika ada informasi yang dibutuhkan oleh pihak luar sekolah pun, dapat juga menggunakan media di dalam website tersebut untuk berinteraksi dengan pihak sekolah. Hal ini menjadikan website sebagai sarana alternatif yang efektif dan efisien dalam komunikasi.

Sumberdaya manusia yang terlibat dalam kegiatan ini adalah dosen yang memiliki kepakaran untuk menyelesaikan persoalan mitra dan mahasiswa yang membantu aspek teknis. Berikut disajikan dalam tabel 2 adalah tugas dan kewajiban masing-masing sumber daya yang terlibat :

Tabel 1. Tugas dan Kewajiban Sumber Daya Manusia yang Terlibat

\begin{tabular}{|c|c|c|c|}
\hline No & Nama & Status & Tugas dan Kewajiban \\
\hline 1 & $\begin{array}{l}\text { Yogiek Indra } \\
\text { Kurniawan }\end{array}$ & Ketua & $\begin{array}{l}\text { - Mengorganisir serta bertanggung jawab terhadap } \\
\text { keseluruhan pelaksanaan kegiatan pengabdian, dari } \\
\text { mengakomodasi informasi, permasalahan, solusi } \\
\text { alternatif, desain pelaksanaan, pemantauan, proposal } \\
\text { dan laporan kegiatan serta komunikasi dengan pihak } \\
\text { sekolah. } \\
\text { - Membuat program aplikasi }\end{array}$ \\
\hline 2 & $\begin{array}{l}\text { Mutia Hidayati } \\
\text { Rahman }\end{array}$ & $\begin{array}{l}\text { Anggota } 2 \\
\text { (Mahasiswa) }\end{array}$ & $\begin{array}{l}\text { - Membantu dalam pembuatan aplikasi. } \\
\text { - Bendahara / mengelola keuangan. }\end{array}$ \\
\hline 3 & Lia Dewi Susanti & $\begin{array}{l}\text { Anggota } 3 \\
\text { (Mahasiswa) }\end{array}$ & $\begin{array}{l}\text { - Sekretaris / administrasi } \\
\text { - Pembantu dan asisten trainer pada saat pelatihan. }\end{array}$ \\
\hline
\end{tabular}




\section{HASIL DAN PEMBAHASAN}

Tahapan dari pelaksanaan pengabdian berupa pembangunan website untuk SMA Negeri Kerjo dapat ditunjukkan oleh gambar 1.

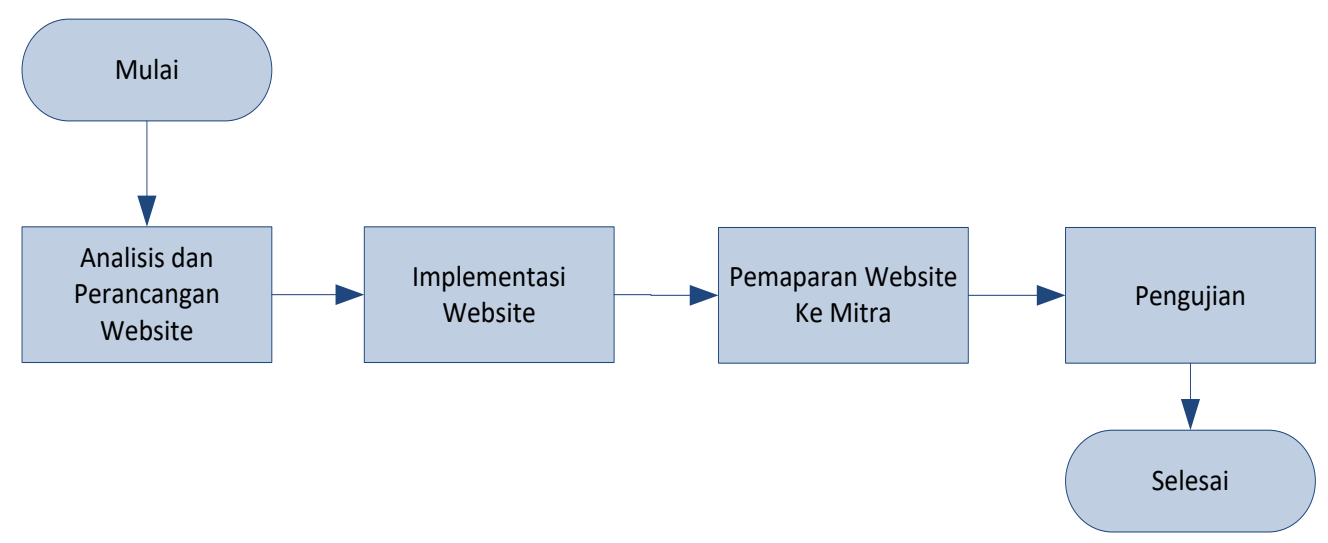

Gambar 1. Tahapan Pelaksanaan Pengabdian

Rincian dari masing-masing tahapan pelaksanaan pengabdian tersebut dapat dijelaskan sebagai berikut :

\section{Analisis dan Perancangan Website}

Pada tahapan ini dilakukan analisis terhadap website yang menjadi solusi dari permasalahan di SMA Negeri Kerjo. Selain itu, dilakukan pula perancangan dari website tersebut agar dapat memenuhi permintaan dari sekolah.

Website informasi sekolah yang dibangun meliputi beberapa modul yang dapat digunakan untuk menjadi solusi dari beberapa permasalahan di sekolah, antara lain :

a. Modul Sekolah, digunakan untuk memberikan informasi mengenai sekolah beserta dengan kondisi real di sekolah tersebut, seperti visi dan misi, sejarah sekolah, fasilitas, kondisi guru dan tenaga pendidik, serta prestasi sekolah.

b. Modul Berita, digunakan untuk memberikan informasi kepada publik maupun siswa sekolah mengenai berita terkini yang terjadi di SMA Negeri Kerjo.

c. Modul Gallery, digunakan untuk menampilkan foto maupun video yang dapat memberikan gambaran real tentang kegiatan yang terjadi di sekolah maupun kondisi sekolah.

d. Modul Buku Tamu, digunakan oleh pihak luar sekolah untuk bertanya kepada sekolah mengenai berbagai macam hal. Pihak sekolah dapat membalas setiap pertanyaan yang diajukan oleh pihak di luar sekolah tersebut.

e. Modul PPDB, digunakan oleh pihak sekolah untuk menampilkan informasi Penerimaan Peserta Didik Baru, baik terkait informasi, tata cara pendaftaran, sampai pengumuman peserta didik yang diterima maupun tidak diterima.

f. Modul Download Materi oleh siswa sekolah untuk melakukan upload materi oleh guru agar bisa di download langsung oleh siswa di sekolah.

g. Modul Pengumuman yang berisi pengumuman maupun informasi penting yang disampaikan oleh pihak sekolah untuk siswa. 
h. Modul Kegiatan Ekstrakurikuler yang berisi informasi update mengenai segala macam kegiatan ekstrakurikuler yang ada di sekolah.

Di dalam website informasi sekolah tersebut, terdapat 2 pengguna (user) / hak akses yang dibedakan dari login, yaitu :

a. Administrator

Administrator bertugas untuk mengelola website beserta konten di dalamnya, termasuk informasi, gallery foto dan video, buku tamu, materi sekolah maupun informasi PPDB.

b. Pengguna Umum

Pengguna umum adalah siswa-siswa di sekolah maupun pihak luar sekolah yang dapat mengakses website informasi SMA Negeri Kerjo menggunakan koneksi internet. Pengguna tersebut dapat melihat semua informasi yang disampaikan dari pihak sekolah melalui website dengan cara memasukkan alamat website ke dalam web browser.

2. Implementasi Website

Setelah dilakukan analisis dan perancangan, tahapan berikutnya adalah implementasi dari website SMA Negeri Kerjo. Implementasi dari website tersebut dibangun menggunakan bahasa pemrograman PHP dengan database MySQL. Untuk image editor menggunakan adobe photoshop, sedangkan untuk text editor yang digunakan adalah sublime text. Website SMA Negeri Kerjo ini menerapkan HTML 5 dan CSS 3 dengan tampilan web responsive (tampilan menyesuaikan dari device yang digunakan), sehingga website apabila dibuka dengan menggunakan web browser di PC, table dan handphone memberikan tampilan yang berbeda. Pembuatan website membutuhkan waktu selama 1 bulan mulai dari perancangan sampai pengujian fitur dan fungsionalitas.

Setelah selesai, website tersebut diunggah ke dalam server dan diberikan domain alamat http://smankerjo.sch.id. Tampilan awal dari website informasi SMA Negeri Kerjo dapat diperlihatkan pada gambar 1. Website tersebut dapat diakses di url : http://smankerjo.sch.id dengan menggunakan PC, laptop, tablet maupun handphone yang terkoneksi jaringan internet. 


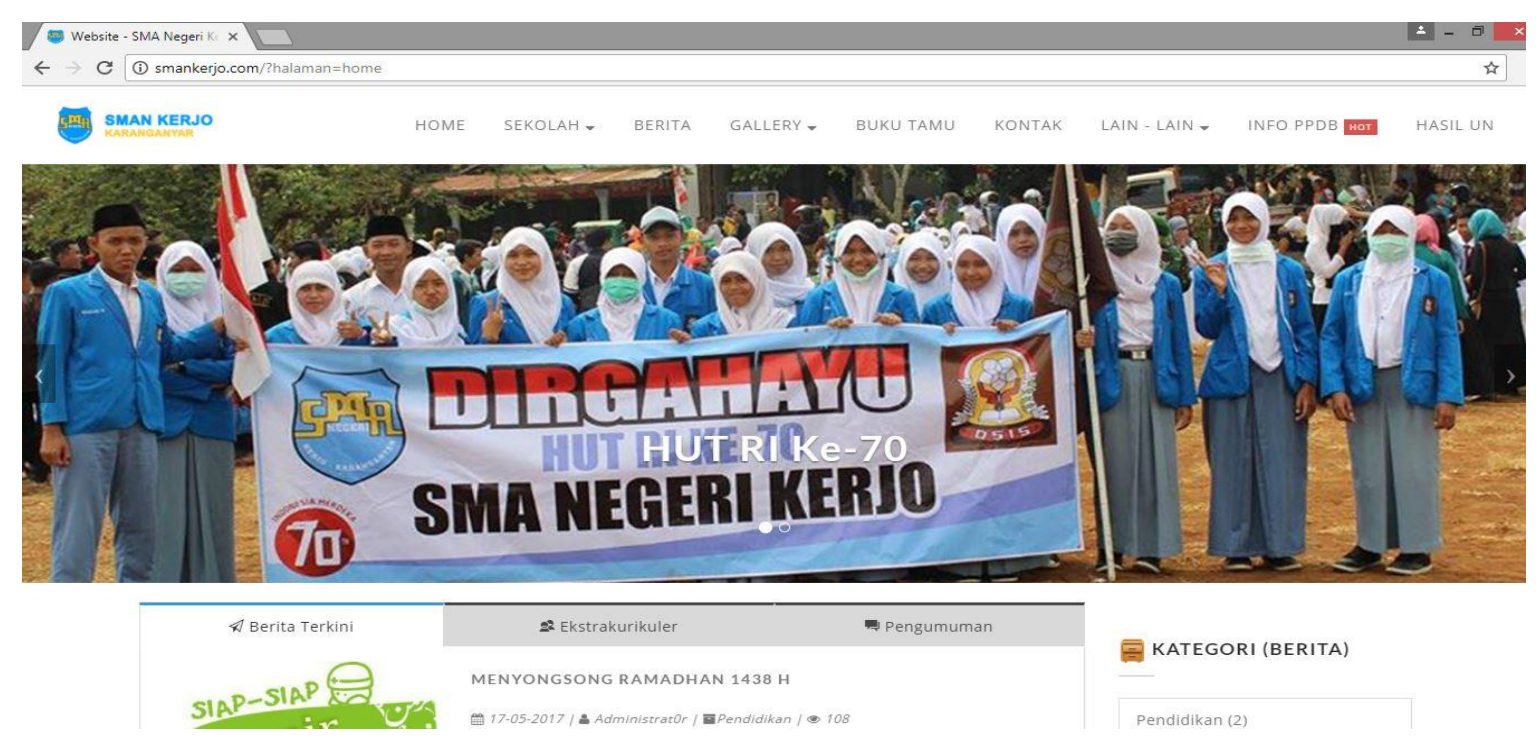

Gambar 1. Halaman Awal Website Informasi SMA Negeri Kerjo

Terdapat beberapa fitur dan fungsionalitas dari website SMA Negeri Kerjo yang difungsikan untuk memenuhi permintaan dari sekolah, diantaranya adalah :

a. Modul Sekolah, berisi semua informasi tentang sekolah seperti visi dan misi, sejarah sekolah, fasilitas, kondisi guru dan tenaga pendidik, serta prestasi sekolah. Gambar 2 menunjukkan contoh tampilan untuk fasilitas sekolah.

표 smankeruo HOME SEKOLAH - BERITA GALLERY - BUKU TAMU KONTAK LAIN - LAIN - INFO PPDB HoT

FASILITAS

Gedung yang dimiliki sekolah

\begin{tabular}{|c|c|c|c|c|c|c|}
\hline \multirow[t]{2}{*}{ No } & \multirow[t]{2}{*}{ Jenis } & \multicolumn{2}{|c|}{ Keberadaan } & \multirow[t]{2}{*}{ Luas ( $\mathrm{m} 2)$} & \multicolumn{2}{|c|}{ Fungsi } \\
\hline & & Ada & $\begin{array}{l}\text { Tidak } \\
\text { Ada }\end{array}$ & & Ya & Tidak \\
\hline 1 & Ruang Kepala Sekolah & Ada & & 21 & Ya & \\
\hline 2 & Ruang Wakil Kepala Sek & Ada & & 32 & Ya & \\
\hline 3 & Ruang guru & Ada & & 105 & Ya & \\
\hline 4 & $\begin{array}{l}\text { Ruang Layanan Bimbingan } \\
\text { dan Konseling }\end{array}$ & Ada & & 64 & Ya & \\
\hline
\end{tabular}

圆 KATEGORI (BERITA)

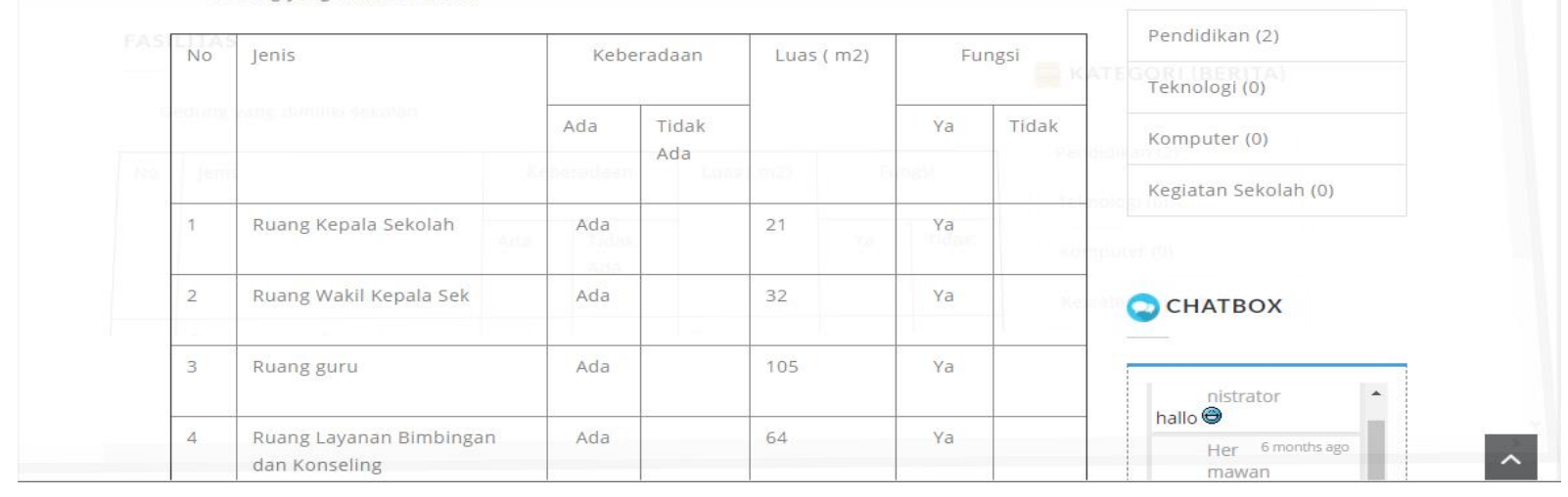

Gambar 2. Tampilan Website Untuk Fasilitas Sekolah

b. Modul Berita, berisi tentang informasi kepada publik maupun siswa sekolah mengenai berita terkini yang terjadi di SMA Negeri Kerjo. Gambar 3 menunjukkan contoh tampilan untuk sebuah berita. 


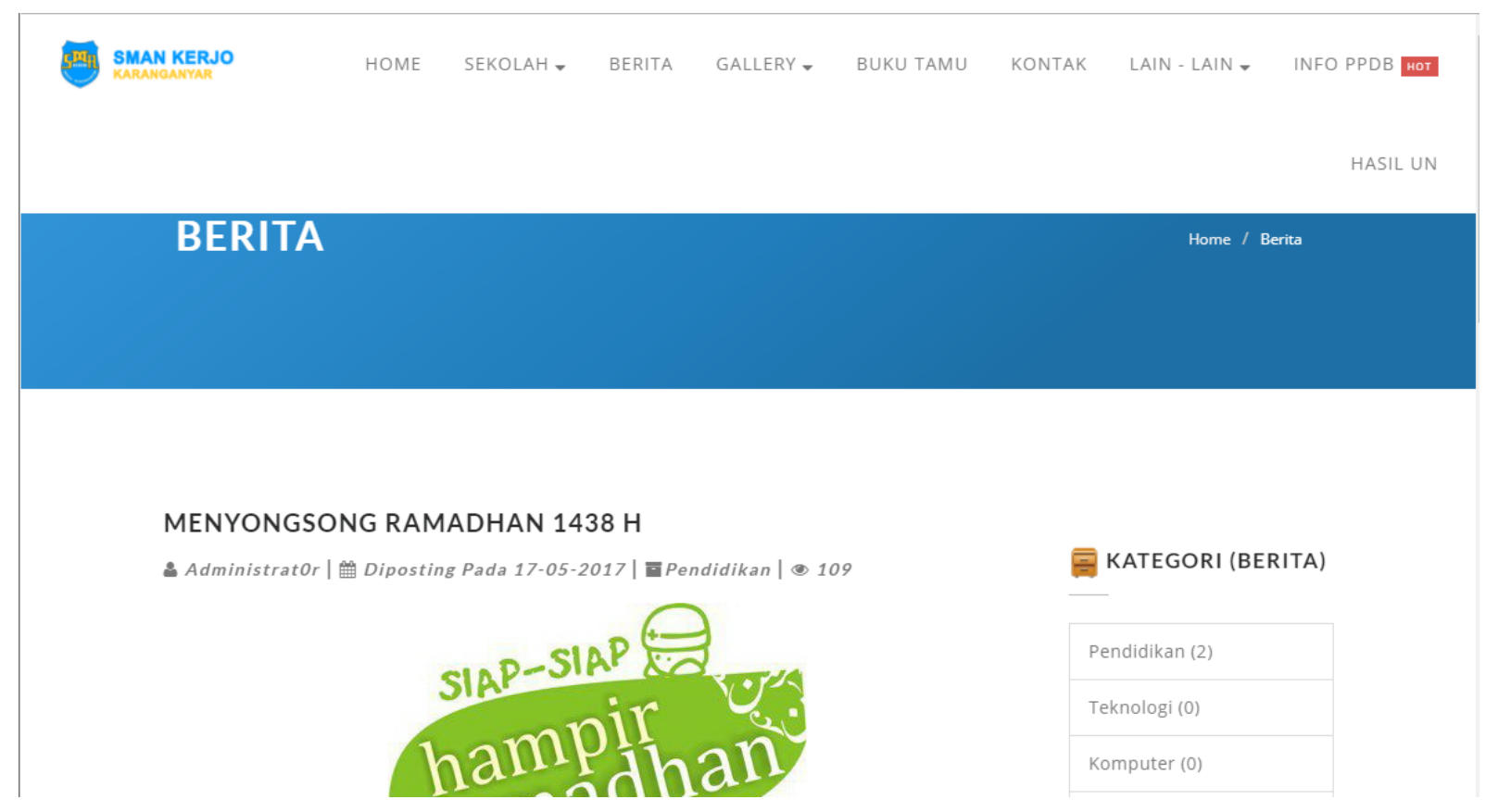

Gambar 3. Tampilan Website Untuk Berita

c. Modul Gallery, berisi tentang seluruh foto dan video yang berkaitan dengan SMA Negeri Kerjo. Gambar 4 menunjukkan contoh untuk menampilkan foto di website.

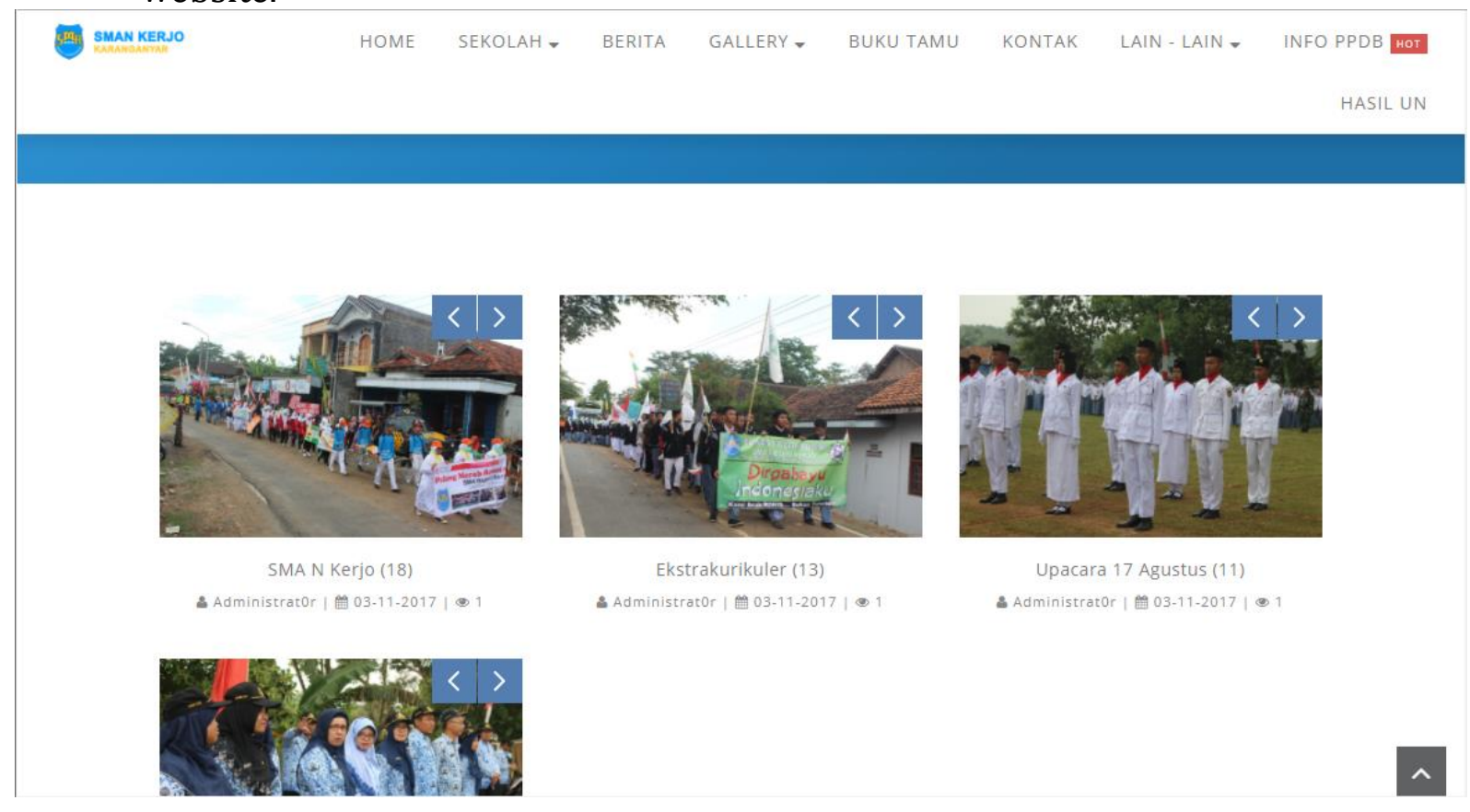

Gambar 4. Tampilan Website Untuk Foto

d. Modul Buku Tamu, berisi tentang seluruh pengunjung dengan komentar yang telah dimasukkan beserta dengan sebuah form untuk memasukkan komentar ke dalam website. Pihak sekolah juga dapat memberikan balasan atas komentar maupun pertanyaan yang diajukan di website tersebut. Gambar 5 menunjukkan tampilan website untuk buku tamu. 
Kurniawan, Pengembangan Website Informasi....123

\section{BUKU TAMU SMA N KERJO \\ KARANGANYAR}

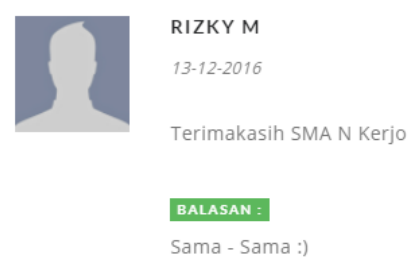

Gambar 5. Tampilan Website Untuk Buku Tamu

e. Modul PPDB, berisi tentang informasi Penerimaan Peserta Didik Baru, baik terkait informasi, tata cara pendaftaran, sampai pengumuman peserta didik yang diterima maupun tidak diterima. Gambar 6 menunjukkan contoh tampilan untuk info PPDB.

I0 SMAN KERJO HOME SEKOLAH - BERITA GALLERY — BUKU TAMU KONTAK LAIN - LAIN - INFO PPDB HOT
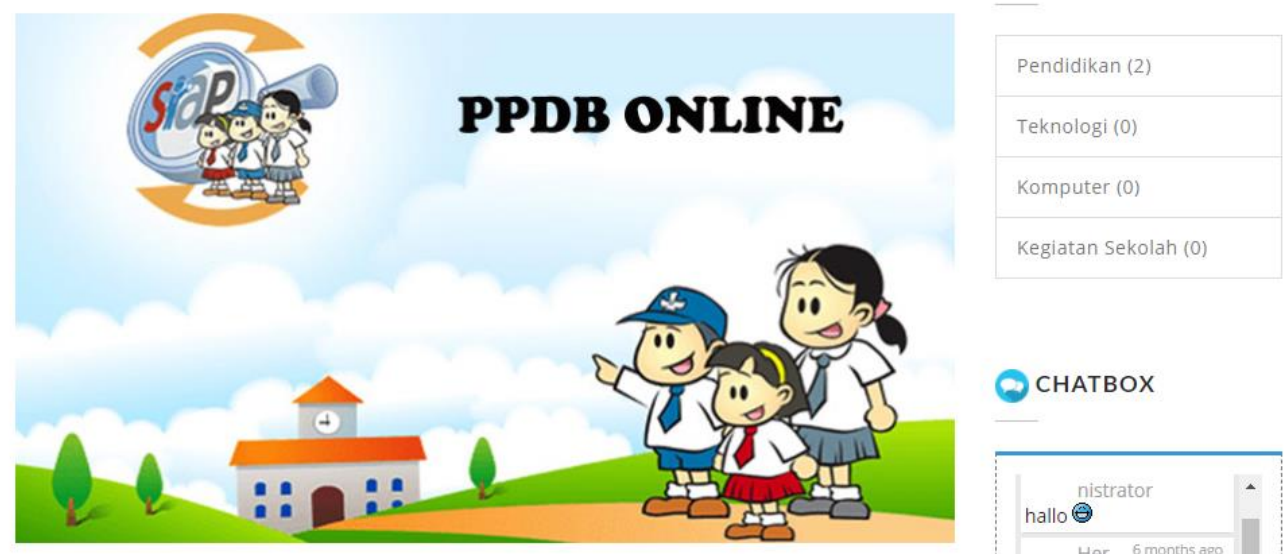

CHATBOX hallo $\Theta$

Gambar 6. Tampilan Website Untuk Informasi PPDB

f. Modul Download Materi berisi tentang semua materi maupun bahan yang dapat di download oleh siswa di SMA Negeri Kerjo tersebut. Gambar 7 menunjukkan tampilan untuk download materi. 
TATA TERTIB SISWA SMA N KERJO

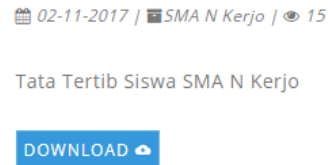

LAPORAN QUESIONER VISI MISI

02-11-2017 / | SMAN Kerjo / 12

Laporan Quesioner Visi Misi
KATEGORI

(DOWNLOAD)

Materi (0)

SMA N Kerjo (7)

CHATBOX

hallo $\odot$

Her 6 months ago

\section{Gambar 7. Tampilan Website Untuk Download}

g. Modul Kegiatan Ekstrakurikuler, berisi tentang informasi dari semua ekstrakurikuler yang ada di sekolah. Gambar 8 menunjukkan tampilan website untuk informasi ekstrakurikuler.

\section{EKSTRAKURIKULER}

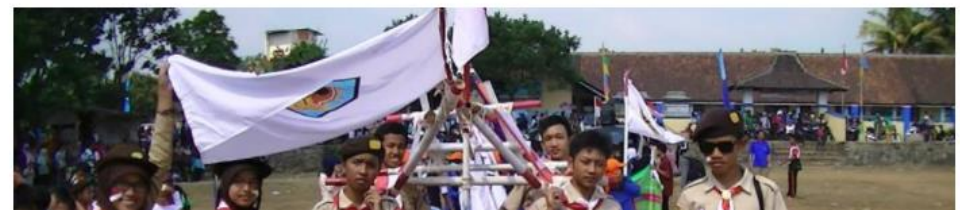

Gambar 8. Tampilan Website Untuk Ekstrakurikuler

Untuk pengaturan segala informasi maupun isi dan konten dari website SMA Negeri Kerjo, terdapat hak akses khusus untuk administrator. Ketika administrator telah melakukan login, maka terdapat beberapa menu yang dapat digunakan untuk mengatur isi konten dari website tersebut. Gambar 9 menunjukkan tampilan website bagi administrator. 


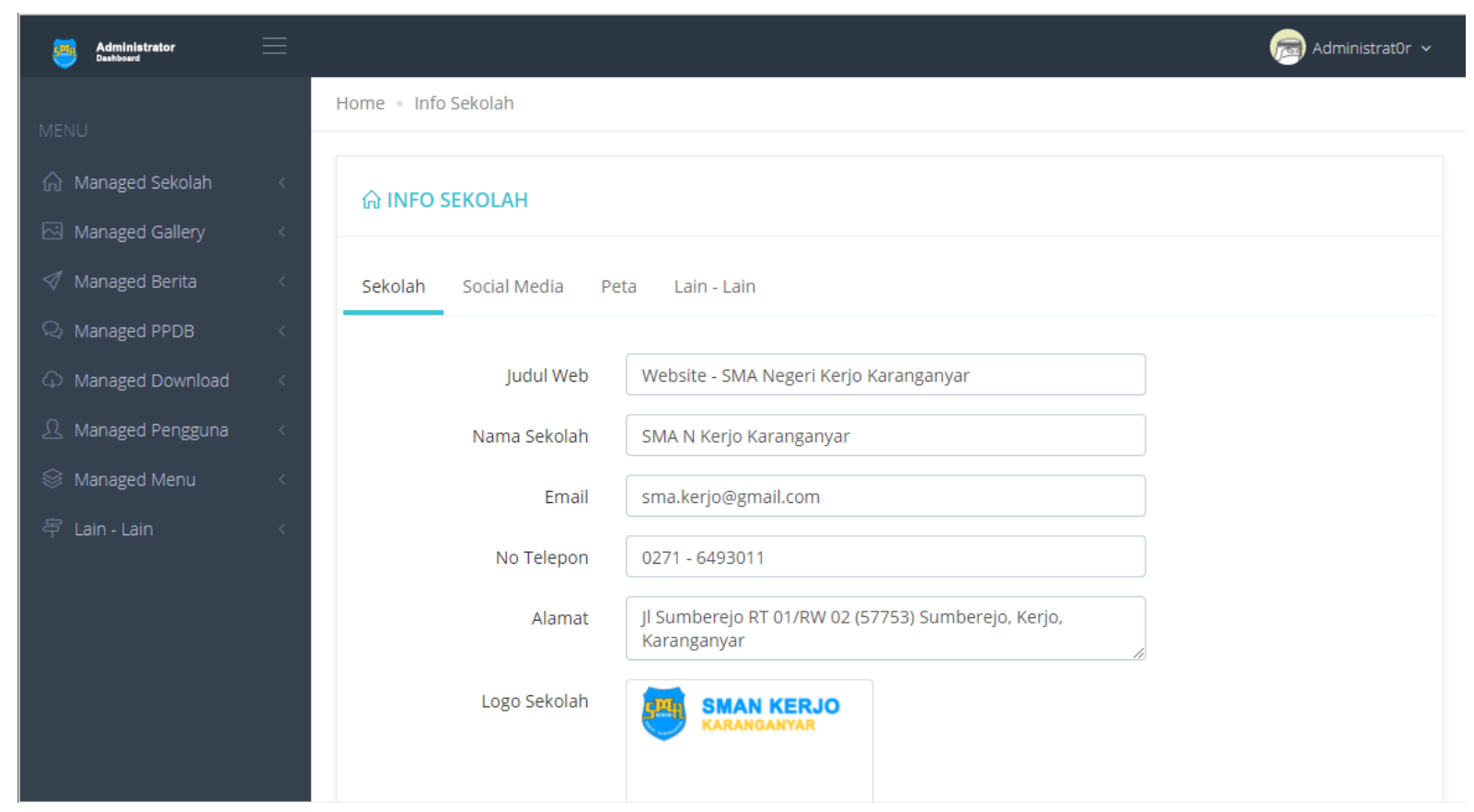

\section{Gambar 9. Tampilan Website Untuk Administrator}

Beberapa menu yang dapat digunakan oleh administrator untuk mengatur konten dari website tersebut adalah :

a. Managed Sekolah, digunakan untuk mengatur isi dari informasi sekolah, seperti visi dan misi, sejarah sekolah, fasilitas, guru dan staff, prestasi, serta tujuan sekolah.

b. Managed Gallery, digunakan untuk menambah, menghapus, serta melakukan edit untuk foto dan video yang ditampilkan di website.

c. Managed Berita, digunakan untuk menambah, menghapus, serta melakukan edit berita yang ditampilkan di website.

d. Managed PPDB, digunakan untuk menambah, menghapus, serta melakukan edit informasi PPDB yang ditampilkan di website.

e. Managed Download, digunakan untuk menambah, menghapus, serta melakukan edit materi yang dapat di download oleh pengunjung website.

f. Managed Pengguna, digunakan untuk menambah, menghapus, serta melakukan edit pengguna seperti guru, maupun administrator di website.

g. Managed Menu, digunakan untuk menambah, menghapus, serta melakukan edit menu-menu yang ditampilkan di website.

h. Lain-Lain, digunakan untuk menambah, menghapus, serta melakukan edit terhadap pengumuman, buku tamu, serta link-link yang terkait di website.

3. Pemaparan Website Ke Mitra

Setelah website informasi sekolah tersebut selesai dibangun, kemudian diadakan sebuah pertemuan untuk membahas fitur-fitur dari website sekolah serta pelatihan kepada pegawai terkait yang nantinya menjadi administrator untuk mengurusi website tersebut. Berdasarkan Kurniawan (2017), pemaparan kepada pengguna maupun mitra dibutuhkan untuk memberikan pemahaman kepada mitra tentang sistem yang berjalan. 
Oleh sebab itu, dilakukan pemaparan website ke SMA Negeri Kerjo untuk memberikan pemahaman kepada pengguna yang bertindak sebagai administrator nantinya.

Kegiatan pendampingan dan pemaparan website tersebut dilaksanakan pada hari Jumat, tanggal 15 Desember 2018. Kegiatan tersebut dihadiri oleh 2 orang staf Tata Usaha yang diberikan wewenang oleh Kepala Sekolah untuk menjadi administrator dari website SMA Negeri Kerjo. 2 orang tersebut dapat diperlihatkan oleh table 2.

Tabel 2. Peserta Pendampingan Pemaparan Website

\begin{tabular}{ccc}
\hline No & Nama & Jabatan \\
\hline $\mathbf{1}$ & Arditya Tri Wahyudi, S.Pd & Kepala Tata Usaha \\
\hline $\mathbf{2}$ & Agus Yudianto & Staf Tata Usaha \\
\hline
\end{tabular}

Metode yang digunakan dalam pemaparan tersebut adalah pelatihan serta tanya jawab secara langsung. Trainer menjelaskan mengenai cara menggunakan website beserta cara pengaturan seluruh konten dari website. Setelah itu, peserta diminta untuk mencoba mempraktekkan secara langsung setiap menu dan fungsionalitas yang telah diajarkan. Alokasi waktu untuk kegiatan pendampingan ini disajikan dalam tabel 3.

Tabel 3. Alokasi Waktu Untuk Kegiatan Pendampingan

\begin{tabular}{lc}
\hline \multicolumn{1}{c}{ Kegiatan } & Alokasi Waktu \\
\hline Pembukaan & 5 menit \\
Sesi 1: Pelatihan Menu Website Informasi Sekolah SMA Negeri Kerjo & 90 menit \\
Sesi 2: Sesi Tanya Jawab dan Saran Pengembangan Website & $\mathbf{2 0}$ menit \\
\hline Penutupan & 5 menit \\
\hline
\end{tabular}

Diharapkan dengan adanya pelatihan tersebut, maka pegawai yang menjadi administrator dari website informasi sekolah akan mengetahui setiap fitur, modul, serta cara penggunaan dari website tersebut.

\section{Pengujian}

Setelah implementasi dan pelatihan dilakukan, tahapan terakhir adalah pengujian terhadap website informasi SMA Negeri Kerjo. Pada tahapan ini, dipilih 30 orang peserta yang terdiri dari 3 orang guru SMA Negeri Kerjo, 2 orang Tata Usaha sebagai administrator, 20 orang siswa serta 5 orang tua siswa sebagai responden untuk mengisi kuesioner yang telah disediakan.

Daftar pertanyaan yang diberikan kepada 30 responden tersebut dapat diperlihatkan oleh gambar 10. 


\section{Petunjuk Pengisian Kuesioner :}

Berikan tanda checklist pada salah satu kolom di antara Sangat Setuju, Setuju, Tidak Setuju atau Sangat Tidak Setuju pada pertanyaan-pertanyaan berikut ini.

Setelah mencoba menggunakan website SMA Negeri Kerjo yang telah diakses melalui url Http://smankerjo.com, Menurut anda :

\begin{tabular}{|l|l|l|l|l|}
\hline Daftar Pertanyaan & $\begin{array}{c}\text { Sangat } \\
\text { Setuju }\end{array}$ & Setuju & $\begin{array}{c}\text { Tidak } \\
\text { Setuju }\end{array}$ & $\begin{array}{c}\text { Sangat Tidak } \\
\text { Setuju }\end{array}$ \\
\hline $\begin{array}{l}\text { Apakah website SMA Negeri Kerjo sudah dapat } \\
\text { memberikan informasi mengenai hal-hal yang } \\
\text { berkaitan dengan sekolah, berita serta kegiatan } \\
\text { sekolah dengan baik? }\end{array}$ & & & & \\
\hline $\begin{array}{l}\text { Apakah website SMA Negeri Kerjo sudah dapat } \\
\text { menjadi alat promosi yang lebih baik daripada } \\
\text { poster dan flier yang ada selama ini? }\end{array}$ & & & & \\
\hline $\begin{array}{l}\text { Apakah website SMA Negeri Kerjo sudah layak } \\
\text { untuk digunakan? }\end{array}$ & & & & \\
\hline
\end{tabular}

Gambar 10. Tampilan Website Untuk Administrator

Setelah dilakukan pengisian kuesioner oleh 30 orang responden, hasil pengujian tersebut dapat ditunjukkan oleh tabel 4:

Tabel 4. Hasil Pengisian Kuesioner

\begin{tabular}{|c|c|c|c|c|c|c|}
\hline Daftar Pertanyaan & $\begin{array}{c}\text { Sangat } \\
\text { Setuju } \\
(4)\end{array}$ & $\begin{array}{c}\text { Setuju } \\
\text { (3) }\end{array}$ & $\begin{array}{l}\text { Tidak } \\
\text { Setuju } \\
\text { (2) }\end{array}$ & $\begin{array}{l}\text { Sangat } \\
\text { Tidak } \\
\text { Setuju } \\
\text { (1) }\end{array}$ & $\begin{array}{l}\text { Jumlah Skor } \\
\text { (Bobot x } \\
\text { Jumlah } \\
\text { responden) }\end{array}$ & Persentase \\
\hline $\begin{array}{l}\text { Apakah website SMA Negeri } \\
\text { Kerjo sudah dapat } \\
\text { memberikan informasi } \\
\text { mengenai hal-hal yang } \\
\text { berkaitan dengan sekolah, } \\
\text { berita serta kegiatan sekolah } \\
\text { dengan baik? }\end{array}$ & 26 & 4 & 0 & 0 & 116 & $96,67 \%$ \\
\hline $\begin{array}{l}\text { Apakah website SMA Negeri } \\
\text { Kerjo sudah dapat menjadi } \\
\text { alat promosi yang lebih baik } \\
\text { daripada poster dan flier yang } \\
\text { ada selama ini? }\end{array}$ & 25 & 5 & 0 & 0 & 115 & $95,83 \%$ \\
\hline $\begin{array}{l}\text { Apakah website SMA Negeri } \\
\text { Kerjo sudah layak untuk } \\
\text { digunakan? }\end{array}$ & 28 & 2 & 0 & 0 & 118 & $98,33 \%$ \\
\hline \multicolumn{7}{|c|}{$\begin{array}{l}\text { Dari hasil pengujian diatas, dilakukan perhitungan dengan mengkalikan bobot } \\
\text { (Sangat Setuju diberikan bobot } 4 \text {, Setuju diberikan bobot } 3 \text {, Tidak Setuju diberikan } \\
\text { bobot } 2 \text { dan Sangat Tidak Setuju diberikan bobot } 1 \text { ) dengan jumlah responden. Setelah } \\
\text { didapat jumlah skor, maka dicari persentase dengan membagi jumlah skor dengan nilai } \\
\text { total maksimal skor yang bisa didapat (bobot } 4 \text { x } 30 \text { responden }=120 \text { ), sehingga didapat } \\
\text { persentase dari setiap pertanyaan tersebut. }\end{array}$} \\
\hline
\end{tabular}


Dari hasil pengujian tersebut, didapat hasil bahwa 96,67\% responden menyatakan bahwa website SMA Negeri Kerjo sudah dapat memberikan informasi mengenai hal-hal yang berkaitan dengan sekolah, berita serta kegiatan sekolah dengan baik, 85,83\% responden menyatakan bahwa website SMA Negeri Kerjo sudah dapat menjadi alat promosi yang lebih baik daripada poster dan flier yang ada selama ini serta 98,33\% responden menyatakan bahwa website SMA Negeri Kerjo sudah layak untuk digunakan. Hal ini menunjukkan bahwa website SMA Negeri Kerjo sudah dapat menyelesaikan permasalahan promosi serta penyampaian informasi yang sulit di SMA Negeri Kerjo.

\section{SIMPULAN}

Dari uraian serta pengujian yang telah dilakukan, dapat diambil beberapa kesimpulan sebagai berikut :

1. Website SMA Negeri Kerjo telah dibangun dengan beberapa fitur, antara lain : modul sekolah, modul berita, modul gallery, modul buku tamu, modul PPDB, modul download materi, modul pengumuman, serta modul kegiatan ekstrakurikuler.

2. Terdapat 2 hak akses pada website, yaitu pengunjung serta administrator. Administrator memiliki kemampuan untuk mengatur isi konten website yang terdiri dari pengaturan : informasi sekolah, gallery, berita, info PPDB, download materi, pengguna, menu, pengumuman, buku tamu serta link terkait.

3. Sebanyak $96,67 \%$ responden menyatakan bahwa website SMA Negeri Kerjo sudah dapat memberikan informasi mengenai hal-hal yang berkaitan dengan sekolah, berita serta kegiatan sekolah dengan baik

4. Sebanyak $85,83 \%$ responden menyatakan bahwa website SMA Negeri Kerjo sudah dapat menjadi alat promosi yang lebih baik daripada poster dan flier yang ada selama ini

5. Sebanyak 98,33\% responden menyatakan bahwa website SMA Negeri Kerjo sudah layak untuk digunakan.

6. Website SMA Negeri Kerjo sudah dapat menyelesaikan permasalahan promosi serta penyampaian informasi yang sulit di SMA Negeri Kerjo.

\section{UCAPAN TERIMA KASIH(Jika diperlukan)}

Tim pengabdian mengucapkan terima kasih kepada semua pihak yang membantu atas terlaksananya kegiatan ini diantaranya yaitu Prodi Informatika Universitas Muhammadiyah Surakarta serta SMA Negeri Kerjo, Karanganyar yang telah ikut berpartisipasi serta semua elemen yang telah membantu terlaksananya pengabdian ini.

\section{DAFTAR RUJUKAN}

Kurniawan, Y. I. (2017). Pelatihan Aplikasi Pengukuran Minat Kejuruan Siswa Bagi Guru Sekolah Menengah Kejuruan (SMK) Se-Jawa Tengah. Warta LPM, 19(2), 149155.

Marlena, N., \& Sasongko, D. (2012). Pembuatan Website Profil Pada Sekolah Menengah Pertama (SMP) Negeri 2 Kartasura.Speed-Sentra Penelitian Engineering dan Edukasi, 2(3), 07-14. 
Kurniawan, Pengembangan Website Informasi....129

Rahman, A. A., \& Kurniawan, Y. I. (2018). Aplikasi Klasifikasi Penerima Kartu Indonesia Sehat Menggunakan Algoritma Naïve Bayes Classifier. Jurnal Teknologi dan Manajemen Informatika, 4(1).

Suhartanto, M. (2017). Pembuatan website sekolah menengah pertama negeri 3 delanggu dengan menggunakan php dan mysql. Speed-Sentra Penelitian Engineering dan Edukasi, 4(1), 01-08.

Supriyono, H., Sutopo, A., Nursyahid, H., Kurniawan, B. A., Fahrudin, I. N., Handoko, D., \& Kurniawan, D. C. (2016). Penerapan Teknologi WEB Sekolah Bagi SMP dan SMA Muhammadiyah Kartasura. Warta LPM, 19(1), 39-52. 